\title{
THE ENDURING ATLANTA COMPROMISE
}

\section{Black Youth Contending with Home Foreclosures and School Closures in the "New South"}

\author{
LeConté J. Dill \\ Department of Community Health Sciences, School of Public Health, \\ State University of New York, Downstate Medical Center \\ Orrianne Morrison \\ Graduate School of Arts and Sciences, Georgetown University \\ Mercedez Dunn \\ Department of Sociology, University of Michigan
}

\begin{abstract}
Waves of migration to and flight from Atlanta by both White and Black residents and businesses have constantly imagined and re-imagined the city as both politically regressive and racially progressive, and from an environmental health perspective, as both a riskscape and a safe haven. We argue that the persistent racial, social, environmental, and health inequities in Atlanta have been fostered and exacerbated by the exponential growth of the city and the persistent rhetoric of it being "the city too busy to hate." This paper is informed by extant research on housing and transportation policies and processes at work in Atlanta since the end of the Civil War, and in particular, the predatory and subprime lending practices during the past thirty years. This paper examines how young people, living in a neighborhood where over $50 \%$ of the houses are currently vacant and contending with threats of school closures, experience the contemporary foreclosure crisis. Using qualitative data from focus groups with middle school youth, this paper offers youth-informed perspectives and local knowledge by offering responses of marginalized populations in Atlanta who inhabit, rather than flee, their built and social environments.
\end{abstract}

Keywords: Atlanta, African Americans, Youth, Built Environment, Foreclosures, School Closures

Our greatest danger is that in the great leap from slavery to freedom, we may overlook the fact that the masses of us are to live by the productions of our hands and fail to keep in our mind that we shall prosper as we learn to dignify and glorify common labor. It is at the bottom of life we should begin and not the top.

-Booker T. Washington, "Atlanta Compromise," Cotton States and International Exposition (1895)

Du Bois Review, 13:2 (2016) 365-377.

(C) 2016 Hutchins Center for African and African American Research 1742-058X/16 \$15.00

doi:10.1017/S1742058X16000217 


\section{INTRODUCTION}

As W. E. B. Du Bois illuminates in The Philadelphia Negro (1899), a historical framework is important in thinking about the macro-social structures and contemporary issues at the intersection of race and the environment. After engaging in an in-depth study of Black life and social conditions in Philadelphia, Du Bois and his family arrived in Atlanta, Georgia in 1897, where he began to serve as a Professor of Economics, History, and Sociology at Atlanta University, and it is this setting of Atlanta, with such a historical framework, that shapes our inquiry for this paper. Waves of migration to and from Atlanta by both White and Black residents and businesses since the Civil War have constantly imagined and re-imagined the city both as a part of the socially excluded, politically regressive, Southern "Other," and as a racially progressive, exceptional model of the "New South" (Hobson 2010). This paper is situated within this paradox and examines the impact of historic and contemporary zoning and housing policies and practices on the current well-being of Black youth in Atlanta.

At the Cotton States and International Exposition in September of 1895, Booker T. Washington espoused his belief that through hard work and hard-earned respect, African Americans would gain the esteem of White society and eventually achieve full citizenship, including basic education and legal rights (1895). This became known as "The Atlanta Compromise" speech because in it lay assurances that Black people, in pursuit of wealth accumulation and helping to rebuild the South, would not ask for the right to vote, would not demand civil rights, and would not rally for more than vocational and industrial education and training (Du Bois 1903; Myrick-Harris 2006). Less than a decade later, when Atlanta became an urban safe haven for Black people fleeing lynchings and mob violence in the rural South, Du Bois cautioned and even prophesized against Atlanta's Black bourgeoisie's quests of materialism and capitalism at the expense of the entire race:

They of Atlanta turned resolutely toward the future; and that future held aloft vistas of purple and gold:-Atlanta, Queen of the cotton kingdom; Atlanta, Gateway to the Land of the Sun...So the city crowned her hundred hills with factories, and stored her shops with cunning handiwork, and stretched long iron ways to greet the busy Mercury in his coming. And the nation talked of her striving (Du Bois 1903 , p. 64).

Soon thereafter, the Atlanta Race Riot of 1906 illuminated that Washington's conservative accommodationist approach to race relations yielded no positive effects for Black people in Atlanta (Du Bois 1995).

Originally corralled in southwest Atlanta due to racial residential segregation and exclusionary zoning policies and practices, Atlanta's Black residents had begun to create ethnic enclaves and thriving Black Main Streets there by the 1920s, like Sweet Auburn Avenue, Hunter Street, and McDaniel Street. Through the 1950s and 1960s, the city continued to brand itself as "progressive," yet working-class and middle-class White residents began to flee from inner-city Atlanta to the suburbs in a national phenomenon known as "White flight," pulled by government incentives and taking their economic and social resources with them (Kruse 2013).

In response to the "Appeal for Human Rights," a full-page advertisement published on March 9, 1960 in each of the Atlanta daily newspapers by the All-University Student Leadership Group, then-Mayor William B. Hartsfield called Atlanta "the city too busy to hate," dismissing the realities of racism and racial inequities in a city 
touted as constantly moving forward towards progress (Kruse 2013). The Civil Rights and Black Power Movements of the 1950s through the 1970s ushered in an intergenerational transfer of knowledge among those seeking justice and human rights, with Atlanta again being a safe haven, this time for headquarters of organizations such as the Southern Christian Leadership Conference (SCLC) and the Student Non-violent Coordinating Committee (SNCC) (Grady-Willis 2006; Myrick-Harris 2006). However, "Atlanta style" politics involved a small number of collaborators from among Atlanta's Black professional and civic elite acting as spokespersons and decision makers for the entire African-American community in private negotiations with Atlanta's White civic and business elite, without input or consent of working-class and lower-income community members (Brown-Nagin 2011). This paternalistic, "old boy's network" of the "Atlanta style" seems like yet another compromise of direct action towards civil rights. During the Black Power Movement, police presence, curfews, and frequent arrests were fear tactics championed by politicians and journalists attempting to distance Atlanta from other urban cities across the country experiencing civil unrest and serve as examples of more of the city's compromises (Grady-Willis 2006).

\section{Enduring Compromises in Pursuit of Citizenship}

The expansion of Atlanta's economy and the increase of its population since the 1960s has exacerbated racial and economic segregation and contributed to increased income inequality, particularly for the city's Black residents. Urban renewal plans and "redevelopment" projects from developers and policymakers in Atlanta have resulted in the destruction of working-class Black neighborhoods and the forced removal of working-class and low-income Black and White residents in the city's core without sufficient replacement housing (Keating 2010). The city's development plans and projects typically have followed the will of the powerful business elite and have left residents in majority Black neighborhoods in precarious situations. Atlanta's Black leaders continued to follow the "Atlanta style" in seeking changes for the Black community by negotiating development agreements with influential Whites in need of Black support to carry out their political and civic agendas, further crippling the Black community (Myrick-Harris 2006). Larry Keating (2010) argues that the failure of the city's governing elite to engage in practical, long range, and participatory planning was due to its preoccupation with enhancing Atlanta's image rather than creating genuine economic growth. This misdirected economic development, along with the poor quality of the city's public schools, has contributed to the phenomenon of "Black flight" (Lacy 2007; Pattillo 2013) from the inner city to a growing suburban metropolitan area, and high levels of underemployment and unemployment for the city's remaining Black residents. Under the guise of the Model Cities Program, a large number of singlefamily homes were destroyed in the late-1950s to late-1960s and replaced with multi-family developments that never became fully integrated into the impacted neighborhoods (Georgia Conservancy 2006). Similarly, construction for the Metropolitan Atlanta Rapid Transit Authority (MARTA) rail system, Interstates 75, 85, and 20, the Atlanta Braves Stadium, The Georgia Dome, and upscale Downtown housing continued to displace low-income Black residents living in the central city (Bullard et al., 2000). Atlanta's branding as "the New South," continues to position it as a modern, urban, world-class international city and economic leader, rising from the literal and metaphorical ashes of the post-Civil War and post-Civil Rights eras (Hobson 2010). 
When the last public housing residents were moved out on December 31, 2009, Atlanta became the first city in the nation to eliminate all of its traditional family public housing stock, with no plans to build replacement low-income housing (Ruel et al., 2013). Although some qualified public housing residents were relocated with a voucher subsidy (formerly Section 8) to private market rental housing, such qualifications depend on a number of items, including up-to-date rental and utility payments (Tester et al., 2011). Though the decision by the city to eliminate public housing was said to be based on a desire to deconcentrate poverty, families formerly residing in public housing tended to cluster in the same southwest and northwest Atlanta neighborhoods in which they lived previously, crowding in with family members, in rental properties, or in homeless shelters (Oakley et al., 2013). There are no plans to build replacement low-income housing in an equivalent ratio to the demolished units.

The persistent racial residential segregation endured by Black people in the United States is a powerful predictor of the number and rate of foreclosures in metropolitan areas across the country (Rugh et al., 2015). Black people and predominantly Black neighborhoods have historically been denied access to mortgage lending. Black mortgage applicants are more likely to be rejected regardless of income or loan amount (Holloway and Wyly, 2001). Predatory lending is based on assets rather than ability to repay, and uses deceptive terms and tactics that ultimately result in placing borrowers into situations in which they are not able to repay the mortgage (Cohen 2008). Black borrowers and/or residents living in predominately Black neighborhoods are disproportionately more likely to receive higher cost and high-risk loans, which lowers their disposable incomes and puts them at greater risk of foreclosure (Beeman 2011; Cohen 2008). The foreclosure crisis began at a national scale by early 2007 , and in some places it began as early as 2004 . However, the federal response to the foreclosure crisis was slow, timid, and sometimes ineffective, particularly for homeowners (Immergluck 2015). The predatory and subprime lending practices leading to unaffordable mortgages continued the cycles of disruption of social networks, dismantling of political power, social exclusion, crime, and blight, particularly in Black and lower-income communities nationally (Libman et al., 2012).

There were almost 60,000 foreclosures in the thirteen-county metropolitanAtlanta region in or by 2007 (Immergluck and Lee, 2008). By 2008, the Atlanta Metropolitan Statistical Area (MSA) had the seventeenth highest foreclosure rate among the nation's 100 largest metropolitan areas (Rich et al., 2009). By this time, residents in southwest Atlanta were already painfully aware of the negligence and disinvestment of their communities by the government resulting in blight, such as dilapidated buildings, poor housing conditions, incomplete roads, and broken sewage systems (Redwood et al., 2010). They perceived this as being purposefully done to drive down land costs for potential investors (Redwood et al., 2010). These southwest Atlanta neighborhoods are thought to be the epicenter of the local and national foreclosure crisis (Puckett 2014). In 2006, the Pittsburgh neighborhood in Atlanta had between $29-73 \%$ vacant properties (Puckett 2014). Homeowners either could not pay the property taxes, the mortgages, or some long-term residents passed away and many of their descendants did not want the homes that they inherited (possibly because of the quality of the neighborhood), leaving properties to fall into disrepair and taxes going unpaid (Puckett 2014). Residents expressed that this devastation was "like Hurricane Katrina without the water" (Henry 2010).

\section{Enduring Compromises as "Slow Violence"}

Environmental justice activists have used the term "slow violence" (Nixon 2011) for occurrences of environmental abuse that happen slowly over time, go unnoticed, 
continue unopposed, or are typically not viewed as violence at all (Grieve 2015). From the standpoint of environmental justice activists, the siting of noxious facilities in low-income neighborhoods and communities of color is a form of racism, namely "environmental racism" (Sze 2006). Subsequent planning for urban renewal projects perpetuated what is now a legacy of environmental injustice (Sze 2006). Exclusionary zoning policies restrict access to healthy, non-toxic facilities and equitable public resources for neighborhoods populated by communities of color and low-income populations (Wilson et al., 2008). Such disempowerment and isolation from parts of the city, its resources, and healthy and stable living spaces contributes to oppression and depression of populations (Sze 2006). Therefore, the geo-political management of people (Dotson 2015) through displacement of Black and lower-income residents, urban sprawl, relentless residential segregation, and other neoliberal compromises in the city of Atlanta become forms of environmental injustice and of violence. Atlanta's slow violence has chipped away at its residents since the Civil War, but has persistent and lasting impacts, particularly on the city's Black residents. However, there is a dearth of research which links the intersections of place, race, class, age, and environmental justice.

\section{Youth Perspectives on Compromise}

Homeowners are not the only residents that experience the slow violence in disinvested urban neighborhoods. Young people also view neighborhoods with vacant and abandoned housing as spaces about which no one cares, including city officials (Pitner and Astor, 2008). Vacant properties make youth feel a lack of control over their neighborhood environments and may cause them to adopt an indifferent attitude towards their neighborhoods and the activities that go on there (Teixeira 2015). Such slow violence can also contribute to neighborhood-level violence (Teixeira 2015).

Black youth residing in the epicenter of the foreclosure crisis are marginalized on multiple levels due to their age, race, class, and neighborhood of residence. This paper privileges the voices of these youth, offering perspectives, informed by them, on the impact of the city's enduring compromises. Black youth, as citizens persisting in their neighborhoods, demand that they and future generations deserve more than a compromise and more of an option than to simply move away from their neighborhoods. We consider the following research questions for our inquiry: (1) How does the built and social environment influence how youth navigate through distressed neighborhoods; (2) How do youth conceive of safe and unsafe spaces in their neighborhood; (3) How do youth in distressed neighborhoods conceive of the barriers to and facilitators of "active transport;" (4) How has the national and local foreclosure crisis impacted health risks for youth; and (5) How do the institutions in distressed neighborhoods impact positive youth development?

\section{METHODS}

\section{Ethnographic Approach}

This paper is guided by an ethnographic approach. Ethnography is one of the most important methods for studying youth of color growing up in urban neighborhoods (Burton 1997; Jones 2009). Immersing ourselves in the history and daily activities of the focal neighborhood, in concert with local community agencies and institutions, was critical for this study. 


\section{Focal Neighborhood}

The Pittsburgh Neighborhood was founded in 1883 and established on 554 acres of land in southwest Atlanta, as one of Atlanta's oldest neighborhoods and as a home for industrial, railroad, civil service, and domestic employees migrating from rural Georgia to the urban center of Atlanta (Kelsey 2011). The Pittsburgh neighborhood is named after its counterpart in Pennsylvania, due to the haze of industrial pollution in the air in this part of the city. Pittsburgh is bounded by Metropolitan Parkway, Pryor Road, University Avenue, and the Norfolk Southern Railroad. By the 1920s, Pittsburgh was thought to be "the place to be" for Black Atlantans and home to several Black civic leaders (Kelsey 2011). McDaniel Avenue or "The Avenue," was a ten-block stretch and central place for social activities and for businesses, 95\% of which were owned by Black residents of Pittsburgh (Kelsey 2011). Crogman Elementary School opened in 1923 and was the first elementary school for African Americans in the Atlanta Public School District (Kelsey 2011). However, by the 1950s, the population in Pittsburgh began to drop due to the aforementioned "White flight" and "Black flight," and between the 1970s and 1990s, the population was cut in half due to the proliferation of disinvestment in the community, drug dealing, and crime (Kelsey 2011). Additionally, the construction of Interstate 75/85 during this period estranged the northern tip of Pittsburgh from the rest of the neighborhood, and acreage in the neighborhood was also lost to construction of the MARTA rail system. From 2007 to the present day, Pittsburgh is thought to be the epicenter of local and national foreclosure crisis (Immergluck 2013). The resulting abandonment of homes has left the neighborhood open to multiple of forms of exploitation.

\section{Entrée}

Our entrée to residents, community leaders, and students in the Pittsburgh neighborhood was facilitated by the Pittsburgh Community Improvement Association (PCIA) - a community development corporation (CDC) based in the neighborhood since 1999. The first author met with the Operations Manager in the Fall of 2011 to explain our team's community-engaged research and policy interests. The organization's staff saw a natural link between the community health interests of the organization and those of the research team, and invited the first author to come to monthly community meetings that the organization hosted and facilitated, focused on safety, health, economic development, and environmental justice. Concurrently, the Georgia Department of Transportation and the Safe Routes to School National Partnership had approached PCIA about coming together to create designated safe routes and encouraging "active transport" (McDonald 2007) for the neighborhood's youth, through walking, biking, or skateboarding, to and from the local public schools in the area. With a short-term goal of improving the health and safety of the student population at these schools, the emerging partnership could lay the foundation for improving the health and safety of the larger community. The first author assisted the partnership by creating a policy brief related to the opportunities of engaging in a Safe Routes initiative in Pittsburgh for the health and safety outcomes of the community and to inform possible stakeholders about the initiative. However, questions still remained about the buy-in, facilitators, and barriers of the school staff, parents, and students to walk and bike between their schools and homes, and youth were not highlighted as stakeholders in any of the community meetings. Therefore, the authors proposed exploring some of these questions directly 
with local youth. PCIA has well-established partnerships and buy-in from the local public schools and the administrators and staff there, and assisted in introducing the research team and the project to them.

\section{Data Collection}

To address the aforementioned research questions, after gaining approval from the Institutional Review Board of the Morehouse School of Medicine, we conducted field research in the Pittsburgh neighborhood over a sixteen-month period. As part of an ongoing program of research regarding neighborhood safety, active transport, and health, we used various methods to collect data, including direct and participant observations at monthly community meetings, PTA meetings, and school career days; photo-mapping (Dennis et al., 2009) of "safe" and "unsafe" spaces, as identified by community members; and a total of three focus groups with seventh and eighth grade students attending a middle school in Pittsburgh. We took extensive field notes during this process. Middle school youth were approached and asked if they were willing to participate in focus group interviews aimed at exploring their mobility through Pittsburgh. The youth seemed eager to participate in the focus groups in order to share their stories. Interested youth were provided with information on the risks and benefits of the study and were asked to sign an assent form, and their parents were asked to sign a consent form. School staff advised us that providing food for the participants would be the most appropriate incentive to thank them for their time and insight. With the guidance and support of PCIA staff and administrators and staff at the middle school, we were able to recruit a total of thirtyseven African-American youth participants to join in on a one-hour semi-structured focus group interview, twelve (32\%) were eighth grade girls, ten $(27 \%)$ were seventh grade girls, eight $(22 \%)$ were eighth grade boys, and seven $(19 \%)$ were seventh grade boys. Focus group interviews were co-facilitated by the first and second authors. During the focus group, questions were asked regarding perceptions of their neighborhood, neighborhood institutions, neighborhood safety, and mobility throughout the neighborhood. We initially planned two co-ed focus groups during the students' elective class- the first with a group of seventh graders and the second with the group of eighth graders. During these focus groups, a female teacher passing through the room commented that the girls "won't say anything useful" to the conversion. Although we were taken aback by this remark, we found that many of the female participants dominated the focus group discussion with helpful comments. We decided to add an additional third focus group of only male seventh and eighth grade students in order to make sure that the voices of both genders and all grade ranges in the school were wellrepresented in the discussions. Focus group interview data were taped and later transcribed by the second and third authors.

\section{Analysis}

Analysis was guided by a thematic approach (Emerson et al., 1995). Interview text was read first to identify emergent themes. Emergent themes were initially memberchecked in discussions with the staff from PCIA and the school. The first author re-read interview text to develop detailed codes and subcodes (Saldaña 2012). Then, the second and third authors re-read the transcripts and developed codes and sub-codes separately. To establish inter-rater reliability, all three authors met and discussed the results of their separate analyses, reconciled any inconsistencies, and agreed upon final themes, codes, subcodes, and related definitions for the codebook (Merriam 2014). Next, the Dedoose web-based analytical program was used to aid in sorting and 
management of the qualitative data. Analytic memos were developed that addressed the themes, analytic points, and interpretation of the analytic points (Emerson et al., 1995).

The interview excerpts below contextually illustrate and are representative of the key thematic points that emerged during analysis. These excerpts reveal youth's experiences of Atlanta's enduring compromises.

\section{RESULTS}

\section{"Used to be Good": Neighborhood Nostalgia}

Though just in their early teens, Pittsburgh's middle school youth revel in their past experiences in their neighborhood. When asked what they liked about their neighborhood, they tended to talk in the past tense. They shared:

It used to be a good neighborhood.

It used to be fun to go outside but now you have to worry about things.

It used to be quiet when I was in elementary, and now it's loud, and people always fight outside of school.

Participants are familiar with the history of the neighborhood, which was shared among family members, at neighborhood churches, and at their school. They show their pride for their neighborhood by attending the Annual Pittsburgh Community Reunion, now in its thirtieth year. Although they are young, they still have a sense of nostalgia for their neighborhood's past.

\section{"Now the House is Abandoned": Foreclosures as an Inherited Source of Loss}

Foreclosures in Pittsburgh result in overall instability among households and in the neighborhood. When asked how the neighborhood has changed in the past five years, participants shared their observations on this phenomenon:

Houses may be abandoned because crime increased and people changed, and people either passed away or cannot cope and moved out.

Really loud neighbors caused the family to move and later people broke in. Then it was boarded up and abandoned. Most houses are abandoned because they are foreclosed.

Investors will buy the houses, and the only way you can move in is to rent them.

Participants spoke about the cycles of moving out and moving in caused by the foreclosure crisis. Additionally, they noted the instability of economic and housing insecurity caused by the death of elderly family members. When prompted about how this made them feel, they went on to comment on how such losses further impacted the mental health of Pittsburgh's residents:

The house was foreclosed because their grandmother passed away, and then their parents got on drugs.

Losing homes means losing family and being alone and causes more people to be on drugs.

That family went into depression.

For residents and families impacted by the foreclosure crisis in Pittsburgh, housing loss, mental health, and substance abuse are deeply intertwined. 
Overall, foreclosures cause a sense of abandonment. Participants revealed:

Now, the house is abandoned.

Now, there is one abandoned house and neighbors are not kind.

There are three or four abandoned houses on the street, and you can hear people breaking windows and hear drug dealers.

Pittsburgh is challenging because people want to improve the community, but there are so many abandoned houses.

The abundance of vacant houses in Pittsburgh poses a threat to neighborhood cohesion and sense of safety.

\section{"School Shouldn't Close": Impact of School Closures}

Not long into our data collection, we learned that our focal school was slated for closure by the school district at the end of the following academic year. We realized that the local and national foreclosure crisis also impacts other neighborhood institutions, like schools. Participants also saw this link, as well as other outcomes. Towards the end of each focus group, we asked participants their thoughts on how to make their neighborhood better. Many of them commented on issues related to the school, its importance in their lives, and its impending closure. They remarked:

Like with abandoned homes, I would make them into better schools for everybody. Yeah, just make the homes better and just make better decisions, like don't close down the schools. That affects other people.

Closing the school is bad for teachers and fifth graders who have to find another school.

School shouldn't close because Mr. Randolph [the school's Community Liaison] is like a father.

It makes people feel unsafe when going to a [different] neighborhood [for school] where there will be bullying and rape.

Our participants were overwhelmingly displeased with the looming closure of their middle school. They expressed concerns about being further destabilized, losing critical relationships, and feeling fearful and unsafe. They also felt discounted, as they were not consulted about such policy decisions, though they are members of the population that will be impacted the most.

\section{DISCUSSION}

Foreclosed homes all look

The same, as if the bouse left

In the middle of breakfast

And didn't come back.

—Mary E. Weems, Closure (2011) p. 6

Memory is a tough place. You were there. If this is not the truth, it is also not a lie. There are benefits to being without nostalgia. Certainly nostalgia and being without nostalgia relieve the past.

—Claudia Rankine, Citizen: An American Lyric (2014, p. 64)

Young African Americans experiencing foreclosures in their neighborhoods desperately want their neighborhoods to go back to their previous, thriving state. Our participants' 
frequent use of the past tense in their responses evokes a sense of nostalgia for better days.

Although our participants' past is fairly recent, comparatively, their responses are similar to some of the comments expressed by adults in the neighborhood during community meetings about a previously thriving community to which most residents wish to return. Although the "heyday" of the Pittsburgh community is said to have been in the 1920s according to archival documents, for many of its younger current residents, the "good ole days" appear to be right before the foreclosure crisis hit Pittsburgh in 2006. For our participants, the neighborhood of Pittsburgh evokes memory, similar to Dolores Hayden's (1997) concept of "place memory" or Kristie Dotson's (2015) notion of geopolitical memory. Expanding these notions further, our participants reveal that young people also conjure memory. Their memories of the Pittsburgh of the past in the current context of the foreclosure crisis leave them in a liminal space of uncertainty and instability.

The abandonment and loss from foreclosures, experienced directly or observed, is yet another form of slow violence for Atlanta's marginalized residents. These losses seem to be inherited from previous Black residents in Atlanta, and the foreclosures are the current form of serial displacement (Fullilove 2004; Saegert et al., 2011). In restructuring housing finance in order to rehabilitate housing markets (Immergluck 2015), policymakers should take care to not further harm the very households and neighborhoods that have already borne the brunt of the foreclosure crisis. Pittsburgh's residents experience not only the loss of their homes, but multiple other losses including the loss of physical spaces and access to financial capital, social support networks, goods, and services in their community. Our participants also reveal through their observations that the stress of foreclosures is associated with poor mental health outcomes and risky individual and collective behaviors, such as substance use and abuse, crime, and sexual assault. Some of the abandoned houses become "trap houses" (Teixeira 2015) where people sell drugs and engage in commercial sexual exploitation.

Furthermore, the slow violence of the notification and implementation of our focal school's closure is inextricably linked to the neighborhood's home foreclosure crisis, as a continued form of "redevelopment" (Aggarwal et al., 2012; Davis and Oakley, 2013). As families are pushed out of the neighborhood, the neighborhood's school children are similarly pushed out of their neighborhood school. Our research team realized that there could be no discussion of "safe routes to school" if there are no schools to which to walk, let alone occupied, and safe homes in which to reside. Our participants expressed continued feelings of loss and a lack of belonging, exacerbated by the imminent closing of their school.

The national school closure phenomenon is widely discussed, debated, and researched, with a focus on Chicago, Philadelphia, New York City, and New Orleans (Ewing 2015). Our findings situate Atlanta as an unfortunate emerging hub for school closures. Although our participants acknowledge that they are not critical policy decision makers, their memories and amplified voices of concern and input might serve as forms of resistance and future recovery in their neighborhoods (Ayala and Galletta, 2012). The Pittsburgh neighborhood's emerging community land trust and community teen town hall meetings are two recent housing, educational, and leadership opportunities that point towards hope, equity, and reclamation for former and current residents of the neighborhood and their progeny. Future generations of Atlanta's Black residents deserve more than a compromise.

Corresponding author: Professor LeConté J. Dill, Department of Community Health Sciences, School of Public Health, State University of New York, Downstate Medical Center, 450 Clarkson Avenue, MSC 43, Brooklyn, NY 11203. E-mail: Leconte.Dill@downstate.edu 


\section{ACKNOWLEDGMENT}

Our deepest appreciation to the youth, educators, community organizers, and residents of the Pittsburgh neighborhood of Atlanta, Georgia, whose sharing of their insights and experiences made this study possible. The study was supported by funding from the Centers for Disease Control and Prevention National Center for HIV/AIDS, Viral Hepatitis, STD, and TB Prevention; the Department of Health and Human Services through the Health Resources and Services Administration; and the Office of Minority Health; Kaiser Permanente; Northrop Grumman; the W. K. Kellogg Foundation; and the Spelman College Social Justice Fellowship.

\section{REFERENCES}

Aggarwal, Ujju, Edwin Mayorga, and Donna Nevel (2012). Slow Violence and Neoliberal Education Reform: Reflections on a School Closure. Peace and Conflict: Fournal of Peace Psychology, 18(2): 156-164.

Ayala, Jennifer, and Anne Galletta (2012). Documenting Disappearing Spaces: Erasure and Remembrance in Two High School Closures. Peace and Conflict: Fournal of Peace Psychology, 18(2): 149-155.

Beeman, Angie, Davita Silfen Glasberg, and Colleen Casey (2011). Whiteness as Property: Predatory Lending and the Reproduction of Racialized Inequality. Critical Sociology, 37(1): 27-45.

Brown-Nagin, Tomiko (2011). Courage To Dissent: Atlanta and the Long History of the Civil Rights Movement. New York: Oxford University Press.

Bullard, Robert, Glenn S. Johnson, and Angel O. Torres (Eds.) (2000). Sprawl City: Race, Politics, and Planning in Atlanta. Washington, DC: Island Press.

Burton, Linda M. (1997). Ethnography and the Meaning of Adolescence in High-Risk Neighborhoods. Ethos, 25(2): 208-217.

Cohen, Rick (2008). A Structural Racism Lens on Subprime Foreclosures and Vacant Properties. Columbus, OH: The Kirwan Institute for the Study of Race and Ethnicity and the National Convening on Subprime Lending, Foreclosure, and Race.

Davis, Tomeka, and Deirdre Oakley (2013). Linking Charter School Emergence to Urban Revitalization and Gentrification: A Socio-spatial Analysis of Three Cities. Fournal of Urban Affairs, 35(1): 81-102.

Dennis, Samuel F., Suzanne Gaulocher, Richard M. Carpiano, and David Brown (2009). Participatory Photo Mapping (PPM): Exploring an Integrated Method for Health and Place Research with Young People. Health \& Place, 15(2): 466-473.

Dotson, Kristie (2015). Here Be Dragons: Thinking Decoloniality as a Black Feminist. Paper read at the CUNY Graduate Center, New York, NY, March 27.

Du Bois, William Edward Burghardt (1899). The Philadelphia Negro: A Social Study. Philadelphia, PA: University of Pennsylvania Press.

Du Bois, William Edward Burghardt (1903). The Souls of Black Folk. Chicago, IL: A. C. McClurg \& Co.

Du Bois, William Edward Burghardt (1995). A Litany of Atlanta. In David Levering Lewis (Ed.), W. E. B. Du Bois: A Reader, pp. 441-444. New York: Holt.

Emerson, Robert M., Rachel I. Fretz, and Linda L. Shaw (1995). Writing Ethnographic Fieldnotes. Chicago, IL: University of Chicago Press.

Ewing, Eve (2015). Phantoms Playing Double-Dutch: Why the Fight for Dyett is Bigger than One Chicago School Closing. <http://sevenscribes.com/phantoms-playing-double-dutch-why-thefight-for-dyett-is-bigger-than-one-chicago-school-closing> (accessed August 26, 2015).

Fullilove, Mindy (2004). Root Shock: How Tearing Up City Neighborhoods Hurts America, and What We Can Do About It. New York: One World/Ballantine.

Georgia Conservancy (2006). Pittsburgb: Proud History, Bright Future. Blueprints for Successful Communities. Atlanta, GA: Georgia Conservancy.

Grady-Willis, Winston A. (2006). Challenging U.S. Apartheid: Atlanta and Black Struggles for Human Rights, 1960-1977. Durham, NC: Duke University Press.

Grieve, Sarah (2015). Environmental fustice Witnessing in the Modernist Poetry of Lola Ridge, Muriel Rukeyser, Gwendolyn Brooks, and Elizabeth Bishop. PhD Dissertation, Department of English, Arizona State University.

Hayden, Dolores (1997). The Power of Place: Urban Landscapes as Public History. Cambridge, MA: MIT Press.

Henry, Scott (2010). City Of Blight: The Tough Road to Recovery for Atlanta Neighborhoods Ravaged by Vacant and Foreclosed Homes. Creative Loafing, March 1. 
Hobson, Maurice J. (2010). The Dawning of the Black New South: A Geo-Political, Social, and Cultural History of Black Atlanta, Georgia, 1966-1996. PhD Dissertation, Department of History, University of Illinois at Urbana-Champaign.

Holloway, Steven R., and Elvin K. Wyly (2001). "The Color of Money" Expanded: Geographically Contingent Mortgage Lending in Ätlanta. Fournal of Housing Research, 12(1): 55.

Immergluck, Dan (2008). A Look at the U.S. Mortgage Crisis: Implications for Housing Markets and Communities. Paper read at the Georgia Institute of Technology College of Architecture Research Forum, Atlanta, GA, February 28.

Immergluck, Dan (2013). The Role of Investors in the Single-Family Market in Distressed Neighborboods: The Case of Atlanta. Cambridge, MA: President and Fellows of Harvard College. <http://www.urban.org/sites/default/files/alfresco/publication-pdfs/412743-The-Roleof-Investors-in-the-Single-Family-Market-in-Distressed-Neighborhoods-The-Case-ofAtlanta.PDF> (accessed September 16, 2016).

Immergluck, Dan (2015). Preventing the Next Mortgage Crisis: The Meltdown, the Federal Response, and the Future of Housing in America. Lanham, MD: Rowman \& Littlefield.

Immergluck, Dan, and Yun Sang Lee (2008). An Analysis of Foreclosure Notice Activity in the 5 County Atlanta Metropolitan Area and in City of Atlanta Neigbborbood Planning Units $V, X$ and $Y$ from Fune 2007 to May 2008. Report prepared for the Annie E. Casey Foundation Civic Site, Atlanta, GA, August 12.

Jones, Nikki (2009). Between Good and Ghetto: African American Girls and Inner-City Violence. New Brunswick, NJ: Rutgers University Press.

Keating, Larry (2010). Atlanta: Race, Class and Urban Expansion. Philadelphia, PA: Temple University Press.

Kelsey, Richard Moriba (2011). Pittsburgh: A Sense of Community: Historic Reflections of an Atlanta Neighborbood. Cleveland, OH: Publishing Associates, Inc.

Kruse, Kevin M. (2013). White Flight: Atlanta and the Making of Modern Conservatism. Princeton, NJ: Princeton University Press.

Lacy, Karyn (2007). Blue-chip Black: Race, Class, and Status in the New Black Middle Class. Berkeley, CA: University of California Press.

Libman, Kimberly, Desiree Fields, and Susan Saegert (2012). Housing and Health: A Social Ecological Perspective on the U.S. Foreclosure Crisis. Housing, Theory, and Society, 29(1): $1-24$.

McDonald, Noreen C. (2007). Active Transport to School, 1969-2001. American Fournal of Preventative Medicine, 32(6): 509-516.

Merriam, Sharan B. (2014). Qualitative Research: A Guide to Design and Implementation. San Francisco, CA: John Wiley \& Sons.

Myrick-Harris, Clarissa (2006). The Origins of the Civil Rights Movement in Atlanta, 1880-1910: Part One. In Perspectives. Washington, DC: American Historical Association.

Nixon, Rob (2011). Slow Violence and the Environmentalism of the Poor. Cambridge, MA: Harvard University Press.

Oakley, Deirdre A., Erin Ruel, and Lesley W. Reid (2013). "It was really hard.... It was alright.... It was easy": Public Housing Relocation Experiences and Destination Satisfaction in Atlanta. Cityscape, 15(2): 173-192.

Pattillo, Mary (2013). Black Picket Fences: Privilege and Peril among the Black Middle Class. Chicago, IL: University of Chicago Press.

Pitner, Ronald O., and Ron Avi Astor (2008). Children's Reasoning about Poverty, Physical Deterioration, Danger, and Retribution In Neighborhood Contexts. Fournal of Environmental Psychology, 28(4): 327-338.

Puckett, Mechelle (2014). Mobility in the Neoliberal City: Atlanta's Left Bebind Neighborboods. M.S. Thesis, Department of Geosciences, Georgia State University.

Rankine, Claudia (2014). Citizen: An American Lyric. Minneapolis, MN: Graywaolf Press.

Redwood, Yanique, Amy J. Schulz, Barbara A. Israel, Mieko Yoshihama, Caroline C. Wang, and Marshall Kreuter (2010). Social, Economic, and Political Processes that Create Built Environment Inequities: Perspectives from Urban African Americans in Atlanta. Family $\&$ Community Health, 33(1): 53-67.

Rich, Michael J., Michael Carnathan, and Dan Immergluck (2009). Addressing the Foreclosure Crisis: Action Oriented Research in Metropolitan Atlanta. Washington, DC: Urban Institute and Fannie Mae.

Ruel, Erin, Deirdre A. Oakley, Chandra Ward, Reneé Alston, and Lesley W. Reid (2013). Public Housing Relocations in Atlanta: Documenting Residents' Attitudes, Concerns, and Experiences. Cities, 35: 349-358. 
Rugh, Jacob S., Len Albright, and Douglas S. Massey (2015). Race, Space, and Cumulative Disadvantage: A Case Study of the Subprime Lending Collapse. Social Problems, 62(2): 186-218.

Saegert, Susan, Desiree Fields, and Kimberly Libman (2011). Mortgage Foreclosure and Health Disparities: Serial Displacement as Asset Extraction in African American Populations. Fournal of Urban Health, 88(3): 390-402.

Saldaña, Johnny (2015). The Coding Manual for Qualitative Researchers. Thousand Oaks, CA: Sage.

Sze, Julie (2006). Environmental Justice, Urban Planning, and Community Memory in New York City. In Sylvia Hood Washington, Heather Goodall, and Paul Rosier (Eds.), Echoes from the Poisoned Well: Global Memories of Environmental Injustice, pp. 171-182. Lanham, MD: Lexington Books.

Teixeira, Samantha (2015). Beyond Broken Windows: Youth Perspectives on Housing Abandonment and its Impact on Individual and Community Well-Being. Child Indicators Research, (9)3: 581-607.

Tester, Griff, Erin Ruel, Angela Anderson, Donald C. Reitzes, and Deirdre A. Oakley (2011). Sense of Place among Atlanta Public Housing Residents. Fournal of Urban Health, 88(3): 436-453.

Washington, Booker T. (1895). Atlanta Compromise. Paper read at Cotton States and International Exposition, Atlanta, GA, September 19.

Weems, Mary E. (2011). Closure. Cleveland Heights, OH: Kattywompus Press.

Wilson, Sacoby, Malo Hutson, and Mahasin Mujahid (2008). How Planning and Zoning Contribute to Inequitable Development, Neighborhood Health, and Environmental Injustice. Environmental fustice, 1(4): 211-216. 